\title{
Introduction: Quebecois Theatre without Borders
}

In his book Theatre and Globalization, Patrick Lonergan advances the idea that globalization is transforming the configuration of economic and cultural exchanges, leading to a "deterritorialization of power" that affects both cultural and economic arenas. Power moves from the precise physical location of its exercise to a conceptual space linked to the domination of brands (Lonergan 2I). In this globalized and reconfigured cultural space, it makes sense to reflect upon the position of Quebecois theatre, to examine the strategies and tools that enable a segment of it to cross borders, and to contemplate whether its position on the global cultural stage has something to teach us about the manner in which the players in this relatively small theatre community can play their cards right in this new, international theatre dynamic. Thus the title of this special issue, Quebecois Theatre without Borders, as we have called it, in which the contributors examine the integration of these practices in a framework that exceeds the nation.

Of course, these international exchanges have a long history. Indeed, since the nineteenth century theatre professionals in Quebec have been practicing their craft far beyond the borders of "la belle province," while theatre companies have invested more time in regularly taking their productions abroad. Some theatre companies, such as the Théatre du Nouveau Monde or the Rideau Vert, began touring episodically in the r950s and 1960s. Similarly, some authors from French Canada were staged in Paris or New York prior to I968. However, it is only in that fateful year that the movement really began; Michel Tremblay's plays obtained an international recognition that would pave the way for the subsequent, warm reception of plays written by Normand Chaurette, Daniel Danis, Carole Fréchette, Wajdi Mouawad and their consorts. Within the sphere of theatre directing, it is Robert Lepage who put Quebec on the world map, followed shortly thereafter by creators as different as Denis Marleau and Carbone I4, not to mention the crucial contribution of Cirque du Soleil in the realm of the contemporary circus.

This dynamism may seem surprising, given Quebec's somewhat short theatrical tradition, but it might be explained by the province's connection to two large international networks: the Francophonie and the Anglo-Saxon world. Furthermore, Quebec has a dynamic playwrights centre at its disposal and at least two festivals (the Festival TransAmériques and the Carrefour international de théâtre) that have firmly established themselves in their respective circles, proof that energy invested in the right place contributes greatly to the promotion of a culture. However, none of this would exist without the climate for aesthetic emulation that has prevailed on the performing arts scene in Quebec for nearly forty years. For the purpose of this issue, we use the word "theatre" in the broad sense of "performing arts" or arts de la scène, which is the more commonly used term in French. 
The present issue thus offers an overview of the international ventures of Quebecois theatre. The contributing authors highlight its chief characteristics (dissemination, translation, cultural mediation, etc.) but also certain aspects that are not as commonly known (for instance, the translation of Daniel Danis's plays in Chile). The reader will note the geographical explosion of Quebecois theatre's routes, an itinerary that attests to the variety of Quebecois theatrical practices and their ability to reach diverse audiences despite the great challenges that must be surmounted by those who facilitate the passage of texts and plays whose historical, cultural and linguistic contexts are not always easy to grasp. Neither does the reception of Quebecois works occur without a kind of interfering intercultural "crosstalk;" however, the points of contact seem to outdo these misunderstandings in certain regions of the globe where the wealth of established relationships is striking. It is important to note as well that the cultural dimension is not always the most important factor in these international relationships; rather, formal invention is often the characteristic that ensures that the authors, directors, theatre companies, and festivals established in Quebec attract attention.

Bien entendu, l'invention formelle de Robert Lepage a consolidé son emprise sur le public international. Dans sa contribution à ce dossier, Melissa Poll analyse la " dramaturgie scénographique " pour laquelle Lepage est bien connu, examinant une expérience récente avec ses voisins plus immédiats, les Hurons-Wendat de Wendake, Québec, dans une mise en scène de La Tempête de Shakespeare. Poll montre comment fusionnent dans ce spectacle trois traditions esthétiques importantes, celles de Shakespeare, de Lepage et de la nation huronnewendat (d'ailleurs, Shakespeare au Québec a sa propre histoire qui est impressionnante [voir Lieblein; Drouin]), afin de raconter l'histoire d'une confrontation coloniale dans le Nouveau Monde. En fait, la collaboration avec cette nation amérindienne a engendré ce qui pourrait être le changement le plus significatif du mode de production habituel de Lepage. Ayant lieu sur le territoire des Hurons-Wendat, intégrant expressément son environnement naturel à sa scénographie, cette Tempête n'a jamais fait de tournée. La Tempête de la compagnie théâtrale Ex Machina et de la Nation huronne-wendat représente ainsi dans ce dossier un « ici " précis et durable-l'« ici » d'un territoire naturel intimement lié à l'histoire, la culture et la philosophie d'un peuple. Les enjeux liés à la rencontre artistique et culturelle entre cet "ici " et les " ailleurs » de l'équipe de Lepage, ajoutés à l'emploi de Shakespeare, font l'objet de l'interprétation de Poll.

Dans le cas de la Tempête Wendake, son enracinement dans son lieu de production est un des éléments qui freine sa circulation, engendrant effectivement un double effet : l'« ici » des Premières Nations devient plutôt un « ailleurs » du point de vue des artistes et spectateurs non-autochtones qui ont participé au spectacle. Cependant, dans le cas de Daniel Danis, dramaturge et lauréat de trois Prix du Gouverneur général, un blocage apparent à la circulation internationale s'est paradoxalement révélé à la source de sa renommée. Danis, lui aussi, affirme l'existence d'un lien intime au terroir (en l'occurrence, celui du Saguenay), un lien qu'il façonne et représente dans une langue singulière, créatrice d'images et de néologismes, qui en a poussé plusieurs à entreprendre l'ambitieuse tâche de sa traduction. Dans «Daniel Danis en traduction : problèmes de la traduction du Chant du Dire-Dire en espagnol chilien ", Andrea Pelegrí Kristić précise les balises de la démarche qu'elle a entreprise lorsqu'elle a traduit le texte de Danis datant de 1996, Le chant du Dire-Dire, vers l'espagnol chilien en vue 
de sa mise en scène par la compagnie théâtrale avant-gardiste Tiatro au printemps 20I4. Attirée par l'œuvre de Danis en raison de l'inventivité langagière de ses personnages qui se manifeste dans le récit-dialogue emmêlé de trois frères rassemblés autour d'un objet presque mythique, le dire-dire (le "say-sayer " dans la traduction anglaise de Linda Gaboriau datant de 1997), Kristić confronte dans son article les limites de quelques principes courants qui s'appliquent à la traduction théâtrale en rapport avec l'œuvre stylistiquement complexe de Danis, dont le concept de "jouabilité " qui exige que l'œuvre traduite ait une fluidité qui résonne de la "bonne " manière dans la bouche des comédiens. N'ayant transposé ni l'intrigue, ni les personnages, ni les tournures idiomatiques du Chant de Danis dans un contexte chilien, Kristić a au contraire suivi la théorie traductologique de Hans Vermeer, approche fonctionnaliste selon laquelle la destination du texte dicte les procédés de traduction. Son étude de cas révèle tout autant la richesse sonore de l'univers symbolique de Danis que la singularité du contexte de communication et de production propre à cette compagnie théâtrale émergente de Santiago.

Les principes directeurs et les conditions de la traduction en situation interculturelle font également l'objet de l'étude de Karen Fricker, qui examine la mise en scène de The Beauty Queen of Leenane de Martin McDonagh présentée en 200I au Théâtre La Licorne. Dans ce cas précis, l'« ailleurs » devient un « ici ». Mais selon quels termes et définis par qui? Fricker plonge dans l'analyse de la traduction française de Fanny Britt, ainsi que dans la mise en scène montréalaise de Martin Faucher, montrant que celles-ci sont clairement axées sur le contexte de communication de l'« ici». Selon l'interprétation de Fricker, les marques linguistiques du parler québécois, ainsi que l'affaiblissement des jeux linguistiques ironiques et exagérés de McDonagh que l'on retrouve dans la traduction de Britt, se combinent avec l'esthétique réaliste de la mise en scène afin de reproduire le symbolisme des réalités sociopolitiques de l'Irlande. Si la traduction s'avère réussie dans sa focalisation sur le contexte de réception, alimentant les récits culturels québécois du colonialisme, du retard culturel et de l'émancipation, elle l'est moins, selon Fricker, dans la perspective d'une rencontre interculturelle parvenant à transmettre les particularités, le ton et surtout, difficulté suprême, l'humour noir du texte si caractéristique de la culture d'origine.

En s'attachant à faire lucidement la sociologie du Festival TransAmériques (FTA), festival montréalais de danse et de théâtre, Sylvain Schryburt situe le théâtre québécois dans le contexte élargi des relations internationales, discutant notamment des réseaux institutionnels et des affinités esthétiques prévalant au sein du système festivalier. À l'intérieur de ce système, le Festival TransAmériques joue plusieurs rôles, notamment ceux d'importateur, d'exportateur, d'investisseur et d'arbitre artistique. En suivant la trace de ces relations à l'intérieur des cercles professionnels du FTA, y compris les connexions personnelles son personnel et celui d'autres festivals, ses liens avec des maisons de production et de diffusion, de même qu'en dressant la carte des tournées et des coproductions, Schryburt définit la position du FTA et sa capacité de faire avancer les productions théâtrales ainsi que les artistes de la scène d'un « ici » vers un « ailleurs » de plus en plus étendu, tout en façonnant le champ théâtral québécois par le biais de ses choix de programmation et d'investissement.

This issue was born of the revitalisation of the Société québécoise d'études théâtrales (SQET) [Quebec Society for Theatre Studies] and its reorganization around four main research areas in 20II. "Le théâtre québécois d'hier et d'aujourd'hui" [Quebecois theatre of 
yesterday and today] being one of these areas, members interested in this area quite naturally joined forces to organize a variety of sessions at the SQET's annual meeting, which took place in Montréal during the spring of that same year. In this era of the globalization of culture, it was not difficult to convene several researchers who tackle Quebecois theatre abroad as an object of study. A selection of the papers given at that 201 I conference form the spine of this issue. To further flesh out this foundation, we invited contributions from researchers whose interests intersect with the question of Quebecois theatre beyond its customary geographical and identitary confines.

Whether because of the resistance it has faced in bringing performances to audiences abroad or thanks to the variety of artistic and aesthetic strategies of which it has made use to reach them, Quebecois theatre proves to be a fascinating object of study for anyone seeking to understand how the arrival into the world [la venue au monde] of a culture inevitably summons a kind of musical counterpoint, a contrasting melody. And isn't this counterpoint necessarily an attempt to move toward this new arrival, to introduce itself to it, to make a contribution through its presence and artistic endeavours? Theatre certainly remains one of the most beautiful means of bearing witness to this desire to be present in the world, to commit oneself to it, and to leave one's mark by sharing with others the most intimate facets of a community: language, body, images-intertwined and summoned to reveal themselveswithin the crucible of a unique performance.

\section{Works Cited}

Drouin, Jennifer. Shakespeare in 2uebec: Nation, Gender, and Adaptation. Toronto: U of Toronto P, 20I4. Print.

Lieblein, Leanore. A Certain William: Adapting Shakespeare in Francophone Canada. Toronto: Playwrights Canada P, 2009. Print.

—. "Pourquoi Shakespeare?" Shakespeare Made in Canada: Contemporary Canadian Adaptations in Theatre, Pop Media and Visual Arts. Ed. with Judith Nasby. Guelph: Macdonald Stewart Art Centre, 2007. Print.

Lonergan, Patrick. Theatre and Globalization: Irish Drama in the Celtic Tiger Era. Basingstoke: Palgrave Macmillan, 2009. Print. 